\title{
SIDE-LIGH'T ON A NEW YORK ANTIFEDERALIST LAWYER
}

\author{
By Robert T. Thompson
}

Some years ago Fames Neilson, of the Class of 1866, deposited in the Rutgers Library a large collection of manuscript letters and business papers belonging to bis family. Their value was not fully brougbt out, bowever, until Professor Robert T. Tbompson, of the Department of History, made a study of them for bis book, Colonel James Neilson, A Business Man of the Early Machine Age in New Jersey, I784-1862, recently publisbed by the Rutgers University Press. The present article is an off sboot from the larger study.

$7 \mathrm{HE}$ history of the bitter fight in New York State for and against ratification of the Federal Constitution has been the subject of numerous investigations. At this late date it is not likely that the general outlines of the story will be changed by the reexamination of old materials or by the discovery of new data. The accepted view holds that, broadly speaking, the Federalists included the wealthy men of business in and around New York City, land speculators, owners of manorial estates, and a very able group of lawyers headed by Alexander Hamilton. The Antifederalists, on the other hand, numbered in their ranks the yeoman farmers and the less prosperous townsfolk. In other words, the lines of cleavage between federal and antifederal opinion in New York, as elsewhere, were produced primarily by economic forces. Many students of American political history question the validity of this economic interpretation, unless large exceptions and qualifications are made, but it is not in order to summarize their criticisms here. The letters which follow illustrate the difficulties encountered when sweeping generalizations are made. Each of the writers owed considerable sums of money, one of them being in debtor's prison while he wrote. They also possessed property, both real and personal, and therefore might be classed as creditors. In their status as debtors they should have opposed the Constitution, if the formula of the economic interpreter is correct; but as owners of tangible property assets, they should be found among the supporters of the new framework of government. They were in fact staunch Federalists, but it is 
doubtful whether they arrived at this conclusion by weighing their assets against their liabilities.

A further word of explanation is necessary to make clear the contents of the letters. John Neilson of New Brunswick, New Jersey, and Abraham Lott, former treasurer of the Colony of New York, were claimants to an estate of land, located south of Albany and known as Coeymans' Patent. Their title was not without flaws, one of the most serious being a dispute respecting the boundaries which dated back to the time of the original patentee, Barent Coeymans. In spite of this, they were able to sell thousands of acres after the Revolution to individuals and groups of associates from Connecticut and elsewhere, with the stipulation that the purchasers were to defend their titles. As was feared and probably expected, numerous ejectment suits were instituted when the purchasers tried to take possession, and this litigation was not settled until after the lapse of many years. The writer of the first letter which follows had bought a farm from Neilson and Lott in the disputed area and had united with them in employing Peter W. Yates of Albany to defend their joint claims. Proceedings were begun before the Federal Constitution became an issue, but, so it is alleged, they came to a standstill when the Antifederalist lawyer found that his clients were Federalists. The animosities engendered by the ratification fight remained very much alive after it was over, judging from the following letter written six months after the New York convention had approved the Constitution. ${ }^{1}$

Eleazer Knowles to John Neilson

New Bruns.

The Land of Deep Dystress The Bordors of Dyspair Jan. 29, I789

"Upon our failyour in Geting a hearing at the Circut Cort fols rumers Spred and fols causes were asigned which raised the furies so that like mad

${ }^{1}$ For a detailed criticism of the Federal Constitution, signed by Peter W. Yates and other Antifederalists, see J. Munsell, Annals of Albany, IV, 336-343. Yates had been a leading patriot in the Revolution, and was one of the most prominent lawyers in Albany. It is interesting to note that Lott and Neilson had failed to secure the services of Alexander Hamilton and two other attorneys in New York City whom they consulted. All three professed to be too busy to go to Albany to try the land title cases. But their real reason for not accepting, so Lott charged, was to be found in his inability (and Neilson's) to pay them retainer fees of $\mathfrak{f}_{30}$ to $£_{50}$. William Paterson of New Jersey took a small part in the litigation as one of the attorneys employed by Neilson and Lott. 
men they fell to Possesioning, to cuting and Slashing at our valluable timber $\&^{\circ}$ and by apliing to Mr. Yates I found his jaws set and my Purs emty the tryall Gone over to all appearance till August next, or Longer. Deep in trouble I aplied to Esq. McCarter [McCarty] who informed me we had afronted our Counselor by apearing for Constitution that the Legislatur was oposed to us in Sentiment, and that if we would Se good Days and Secure our intrest, we must change our Pollaticks and become AntefederalsWith a heavy hart an Pocket Light I impatiently waited you comeing here but have heard Nothing Direct from any of you till this moment I received a letter from Mr. Lott Dated Nov. 5th, which asure me of his friend ship and Good intention but the Long time it has had in comeing Destroys much of its Sweets. ... I cannot tell my wants and wory with Pen But hope you will find it in your way to come here and See for your self and feel for your Friend and humble Servant.

Colonel John Neilson seems to have been particularly impressed by Knowles' comment on the Constitution, and naturally so, for he had been one of the men appointed in New Jersey to attend the Federal Convention (although he did not attend), and he had served in the New Jersey convention which had ratified the new constitution unanimously.

John Neilson to Eleazer Knowles

New Bruns.

Feb. 17,1789

I hope the opinion that to secure your interest $\&$ to see good days you must change your Politicks and become Antifederals will ere long discover its impropriety and with its votaries become disregarded, and that the pure principles of the New Constitution with its Advocates will be raised into esteem, even in the State of New York, as the only means of securing the rights and priveleges of the Inhabitants of this country, and of setting the United States of America in an honorable point of view as a nation. . . .

In spite of the fact that he was locked up in debtors' prison in New York City, Abraham Lott was an ardent advocate of the Federal Constitution. His debtor status, it is true, was probably not the usual one. His difficulties arose out of his inability to convert large frozen assets into cash when it was needed. His Federalist bias and his opinion of Peter W. Yates in particular are portrayed in the following:

Abraham Lott to John Neilson

New York

March 20, I789

In my last . . . I hinted that a Bill had passed the Senate for my liberation, and that I anxiously waited the Result of the deliberation of the As- 
sembly thereon. As I expected, so it has happened; the Majority, being truly Antifederal, and therefore, as heretofore, with hearts desperately wicked, and doing evil continually, have not concurred in the bill. Thus I must remain immured, and with patience wait, until the time arrives that we shall have men of honor in the Assembly, and then, but not till then, do I expect justice will be done unto me; and what is of far more importance to the Union of the States. ...

I send you Knowles's Letter by which you will see that P. W. Yates \& our Cousin McCarty want them to be turn Coats; which I, by all means advised them not to be. ... I have advised Mr. Knowles \& others, as P. W. Yates will not open his mouth without 29/ to apply to Mr. Gilbert, of Hudson, who $[s i c]$ you know, and who I am certain will give them better advice than P. W. Yates, as he [Gilbert] is federal and comes from Connecticut. ...2

Under any circumstances it was exasperating to see the determination of the long-pending litigation further postponed, but it was doubly irksome when it seemed to be done deliberately by their own lawyer for his own political purposes. The Federalist clients concluded, however, to swallow their indignation and retain a political foe as one of their counsel. John Neilson gives the reason for this decision.

John Neilson to Abraham Lott

New Bruns.

Feb. 26, 1789-

Mr. Yates's conduct would appear strange from a man of unsullied reputation but not so for one whose character is represented as one wanting integrity; our business is in his hands and too well known by him I suppose for us to quarrel with him, we must therefore submit to the inconvenience of his illiberal behaviour and make the best of our situation [which is] so much in his power. ...

${ }^{2}$ There are a number of statements in the Abraham Lott-John Neilson correspondence which indicate that Lott thought that Connecticut settlers in New York were more tenacious and canny than others in defense of their rights. For this reason he preferred to have them as purchasers in the disputed Cocymans tract. 